\title{
Does Public Spending on Elementary Education Actually Improves Learning Outcome in India?
}

\author{
Dr.Rajeshwari.UR, Assistant Professor, Department of Economics, CHRIST (Deemed to be University), \\ Bangalore-29, rajeshwari.ur@christuniversity.in \\ Dr. Marie Joseph Gerard Rassendren, Associate Professor, Department of Economics, CHRIST (Deemed to be \\ University), Bangalore-29, gerard.rassendren@christuniversity.in
}

\begin{abstract}
This paper tries to examine the link between public spending on elementary education and learning outcomes in India. Learning outcomes basically describes the measurable skills, abilities, knowledge or values that students should be able to demonstrate as a result of completing different levels of education. The study is based on secondary data. Data on expenditure on education have been taken from the Ministry of Human Resources Development (MHRD) and various budget documents. Data on the learning outcomes have been collected from various reports of the Annual Status of Education Report (ASER). The data is limited only to the learning outcomes of rural India. The period of time considered for the study is 2010-2018. The findings of the study reveal that increase in public spending does not mean increase in the learning outcome. The study also shows that the spending on schooling is gradually rising.Although there is a substantial increase in the enrollment ratio, the pupil teacher ratio and the school infrastructure, there has been little improvement in learning outcomes, especially in government schools. The study also shows that the government should focus on expenditures on teachers training which will greatly contribute to learning outcomes.
\end{abstract}

Keywords: Elementary Education, GDP, Government Spending, Learning Outcomes, Development Received: 06.12.2020 $\quad$ Accepted: 22.01.2021 $\quad$ Published: 03.02.2021

\section{INTRODUCTION}

Education is considered to be one of the most important aspects of human development. Without substantial investment in human capital, no country can achieve sustainable development. Many past studies have shown a positive relationship between education and economic development. Findlay and Kierzkowski in 1983 and in 1986, Romer introduced the effect of human capital in terms of endogenous skills in economic development. Young (1991) and Stokey (1988) indicated that learning by doing contributes more to the production. According to Amartya Sen (1999), education is desirable not only for individuals but for society as a whole. Education is an important factor for economic growth and development. At the aggregate level, a better-educated workforce enhances the human capital of a nation.

Elementary education is the most important part of the education system, laying the foundation for the building of education. According to Psacharopoulos and Patrinos (2004), primary education has yielded high social returns in developing countries. In recent years, the focus on achieving universal primary education in most developing countries has increased.A number of past studies have shown that primary education has a direct and positive impact on earnings and productivity.

In India, the landscape of elementary education has changed considerably in the last few decades. The amount and composition of funding for elementary education in India has significantly changed. The Kher Committee (1948-49) recommended that a fixed percentage of central and state revenues should be allocated to education and that around $70 \%$ of expenditure should come from local authorities. The Kothari Commission (1964-66) recommended that the expenditure on education should reach 6\% of GDP by 1986. It also focused on strengthening advanced study centers and setting up a small number of major universities of international standard. The Committee also recommended that at least two thirds of the allocation for school education be prioritized. In addition, in 1986, National Education Policy also emphasized the recommendation of the Kothari Commission. Subsequently, the Sakia Committee (1996) examined the financial implications of the proposal to make free and compulsory education a fundamental right. It also reiterated the need for expenditure of $6 \%$ of GNP and also recommended that $50 \%$ of education spending 
should be on primary education. The National Common Minimum Program and the CABE Committee also had similar recommendations. The CABE Committee also mentioned that public expenditure on elementary education is not sufficient and that additional allocation is required to achieve universalization of elementary education by 2011-12. However, these policy statements and implication of the policies are not going together.

Until the launch of Sarva Shiksha Abhiyana (SSA), funding for elementary education was the primary responsibility of state governments. But after the launch of SSA in 2001, we can see a significant increase in funding for elementary education from the Government of India. The goal of universal elementary education encompasses universal access and retention, bridging gender and social gaps and improving the quality of education through various flagship programmes. In 2003, as universal primary education became a fundamental right, the government provided free primary education through its flagship program, Sarva Shiksha Abhiyana. The basic question, however, is whether public expenditure on elementary education actually improves learning outcomes?

Past studies exploring this issue have shown mixed results. Some papers have found that the relationship between public expenditure on elementary education and learning outcomes is weak. Mingat and Tan (1992), Flug.et.al (1998) have shown that, apart from public spending, other factors such as per capita income, parent perception of cost and benefit, family background and parents' educational level also affect learning outcomes. On the other hand, Galleghar (1993), Mehrotra (1998), Gupta.et.al (2002), Baldacci et al (2008) showed a positive relationship between education spending and outcomes.

Although there has been a fair amount of research on the relationship between public spending and socio-economic outcomes, there have not been as many studies on education spending and learning outcomes. It is important not only to study the impact of public expenditure on the net enrolment ratio, but also the impact on learning outcomes.

Learning outcomes are essentially a reflection of the quality of education. According to Ministry of Human Resource and Development (MHRD) "Learning Outcomes are assessment standards that indicate the expected level of learning that children are expected to achieve for that class. These outcomes can be used as checkpoints to evaluate learning at different points of time. Learning outcomes would help teachers to understand the learning levels of children in their respective classes both individually and collectively". According to the 2016 World Bank Report, during the period 2011-2014, the average learning level of Class V students decreased, while per capita child expenditure increased by more than 200 per cent. Improving the quality of learning has consistently been at the focus of the Sarva Shiksha Abhiyan. SSA Joint Review Missions report a decline in reading ability and numerical ability learning outcomes. It is therefore very important to assess the quality of learning outcomes at different levels.

\section{REVIEW OF LITERATURE}

Kundu and Biswas (2019) investigated learning outcomes at elementary level among children in different states of India. The study considers 24 major states based on ASER reports. The study found that, in most States, children's learning achievement at the elementary level is deteriorating. This study also found that higher parental literacy, the availability of certain school-related factors, such as Mid-Day Meal, proper drinking water, sanitation and playground facilities, can play a positive role in improving the learning performance of rural Indian children at the elementary level.

ThiaJasmina (2016), tried to analyze the impact of government spending on the adjusted-national examination scores at the junior secondary education in Indonesia during the time period 2010-2015. The result shows that central and local government spending has no significant impact on scores, while central government expenditure on teachers and other socio-economic factors are significant determinants.

Anuradha De and Tanuka Endow (2008) examined the level and composition of public expenditure on education and outcome. The main factors considered are the percentage of school with drinking water, electricity, girl's toilet, pupil teacher ratio and gross enrolment ratio. The study found that there is little to show at the elementary level in terms of learning achievement compared to the resources spent in the education sector. Excessive focus on expenditure has resulted in the assessment of physical infrastructure creation, provision of teaching and learning materials, appointment of teachers, etc., rather than the monitoring of the learning process to see how many children have learned.

Iyer (2009) explored the effectiveness of public expenditure on primary education outcomes in 115 districts across three Indian states. The main variables considered for the study include per capita income, 
student-teacher ratio and the ratio of government to private primary schools.The result shows that expenditure on primary education has a negligible impact on the enrolment rate, the rate of transition to primary school and the performance of students in exams. In addition, the study also found that outcomes are more consistent in districts with higher proportions of private primary schools.

François Leclercq (2005) presented a survey of large empiric literature that sought to examine the relationship between expenditure on education and outcomes in both developed and developing countries. The study found that there was a lack of consensus on the results of standard studies using the 'education production function' conceptual framework, whether at the macro or micro level

Samer Al-Samarrai (2003) examined the relationship between public expenditure on education at primary school level in developing countries. The study found a weak relationship between public expenditure and educational outcomes. This does not mean that resources are not important, but that they may not be sufficient to achieve the objectives of education

Many of the previous literature focused on the relationship between public expenditure and the quantitative outcomes like gross enrolment ratio, student teacher ratio, per capita income, etc. Very few studies have considered the relationship between learning outcomes and public expenditure on elementary education. This study therefore seeks to analyze whether public expenditure on elementary education actually improves learning outcomes.

\section{METHODOLOGY}

The study is based on secondary data. Data on expenditure on education have been taken from the Ministry of Human Resources Development (MHRD) and various budget documents. Data on the learning outcomes have been collected from various reports of the Annual Status of Education Report (ASER). The analysis is limited only to the learning outcomes of rural India. The period of time considered for the study is 2010-2018.

The main learning outcomes considered for this study are:

1. \% Children able to read at different levels (Std III, Government schools)

2. \% Children able to read at different levels (Std III, Government schools)

3. \% Children in government schools in Std V who can read Std II level text

4. \% Children in government schools in Std $\mathrm{V}$ who can do division

5. \% Children by grade and arithmetic level All children

The main expenditure indicators considered are:

1. Percentage of Total Expenditure (Education + Other Departments) on Education to GDP

2. Percentage share of Expenditure on Education to the total expenditure (Revenue Account)

3. Sector-wise Expenditure (Plan + Non Plan) on Education by Education Department (Revenue Account) with percentage Centre and States/UTs

4. Percentage of Elementary Plan \& Non Plan expenditure on Education by Education Department (Revenue Account) to the total Plan and Non Plan expenditure

Simple descriptive statistics is used for analysis purpose. Due to the unavailability of the data, the study considers only limited learning outcome indicators.

\section{Data Analysis}

The analysis of the data was carried out in the following four components:

1. Elementary education Trends in four key indicators, i.e. facility indicators, school indicators, enrolment indicators and teacher indicators

2. Trends in allocation and expenditures

3. Trends in learning outcomes

4. Association of expenditure and learning outcome

\section{Elementary Education Trends}

School infrastructure is an important component of the quality of education. Table 1 shows some of the key indicators for elementary school education. All facility indicators show positive performance growth. Favorable attitude towards school infrastructure facilitates motivation to increase school attendance and improves student academic performance. Student-classroom ratio presents average number of pupils sitting in one classroom which has shown consistent improvement over a period of time. The availability of drinking water at school is the most important facility that every school should have. It has steadily improved over a 
period of time.DISE data shows that the percentage of schools with drinking water has increased from $86.8 \%$ in 2007 to $96.8 \%$ in 2015.During the period from 2007 to 2015, the percentage of schools with boy's and girls' toilets increased significantly. Although the percentage of schools with computers has increased, it is much lower than other facility indicators. Even as India excels towards the goal of elementary education for all, its ICT capabilities, as far as school education is concerned, remain severely challenged by the low availability of computers in schools.

Table 1. Facility Indicators

\begin{tabular}{|l|l|l|l|l|l|l|}
\hline & $\begin{array}{l}\text { Student- } \\
\text { Classroom } \\
\text { Ratio }\end{array}$ & $\begin{array}{l}\text { \% of } \\
\text { schools } \\
\text { with } \\
\text { drinking } \\
\text { water }\end{array}$ & $\begin{array}{l}\text { \% of } \\
\text { schools } \\
\text { with boys } \\
\text { toilet }\end{array}$ & $\begin{array}{l}\text { \% of schools } \\
\text { with girls } \\
\text { toilet }\end{array}$ & $\begin{array}{l}\text { \% of Schools } \\
\text { with } \\
\text { Boundary } \\
\text { Walls }\end{array}$ & $\begin{array}{l}\text { \% schools with } \\
\text { computers }\end{array}$ \\
\hline $\mathbf{2 0 0 7}$ & 35 & 86.8 & - & 50.6 & 50.2 & 14.3 \\
\hline $\mathbf{2 0 0 8}$ & 33 & 87.8 & - & 53.6 & 51 & 14.1 \\
\hline $\mathbf{2 0 0 9}$ & 32 & 92.6 & 31 & 58.8 & 51.5 & 16.7 \\
\hline $\mathbf{2 0 1 0}$ & 31 & 92.7 & 42.6 & 60.3 & 55.4 & 18.7 \\
\hline $\mathbf{2 0 1 1}$ & 30 & 94.5 & 81.1 & 72.2 & 58.2 & 20.5 \\
\hline $\mathbf{2 0 1 2}$ & 29 & 94.9 & 67.1 & 88.3 & 59.5 & 22.1 \\
\hline $\mathbf{2 0 1 3}$ & 28 & 95.3 & 94.5 & 84.6 & 61.9 & 23.3 \\
\hline $\mathbf{2 0 1 4}$ & 27 & 96.1 & 95.4 & 87.5 & 64.5 & 25.2 \\
\hline $\mathbf{2 0 1 5}$ & 27 & 96.8 & 97.1 & 97.6 & 64.9 & 26.0 \\
\hline
\end{tabular}

Source: DISE Reports

Table 2 shows some of the important school indicators like primary school per 1000 child population, percentage of single teacher school with more than or equal to 15 enrolment and percentage schools with enrolment less than 50 enrolment. We can notice that the percentage of government school is decreasing over a period of time indicating increase in the private schools. Percentage of single teacher school with more than 15 enrolments has decreased marginally from $9 \%$ to $8.2 \%$.Though RTE stipulates that no school shall have a teacher vacancy of more than 10 per cent but according to MHRD Education Statistics at a glance 2019, government elementary schools have a shortfall of 9.08 lakh teachers against a sanctioned strength of 51.8 lakh posts as on 31.03.2016.

Table 2. School Indicators

\begin{tabular}{|c|c|c|c|c|c|}
\hline Year & $\begin{array}{l}\text { No. of } \\
\text { Districts } \\
\text { Covered } \\
\end{array}$ & $\begin{array}{l}\% \text { of } \\
\text { government } \\
\text { school to } \\
\text { the Total } \\
\text { schools } \\
\end{array}$ & $\begin{array}{l}\text { Primary } \\
\text { School per } \\
1000 \text { Child } \\
\text { population }\end{array}$ & $\begin{array}{l}\% \quad \text { single } \\
\text { teacher } \\
\text { school } \\
\text { with } \\
\text { enr } \geq 15 \\
\end{array}$ & $\begin{array}{l}\% \\
\text { schools } \\
\text { with } \\
\text { enr } \leq 50\end{array}$ \\
\hline 2007 & 624 & 80.183 & 9 & 9 & 25.2 \\
\hline 2008 & 633 & 80.523 & 7 & 8.4 & 26.7 \\
\hline 2009 & 635 & 80.383 & 10 & 8.1 & 27.1 \\
\hline 2010 & 637 & 78.146 & 10 & 7.7 & 27.8 \\
\hline 2011 & 644 & 76.365 & 10 & 7.2 & 28.4 \\
\hline 2012 & 662 & 75.901 & 10 & 8.7 & 29.2 \\
\hline 2013 & 662 & 75.513 & 9 & 7.2 & 31.3 \\
\hline 2014 & 680 & 74.751 & 9 & 6.8 & 32.3 \\
\hline
\end{tabular}


\begin{tabular}{l|l|l|l|l|l|}
2015 & 680 & 74.323 & 9 & 8.2 & 33.5 \\
\hline
\end{tabular}

Source: DISE Reports

Table 3 shows enrolment indicators at the elementary level of education. There is a declining trend in the enrolment of Grade I to Grade V in government school, while retention and transition rates have increased significantly.

Table 3. Enrolment Indicators

\begin{tabular}{|c|c|c|c|c|c|c|}
\hline Year & $\begin{array}{l}\text { Enrolment } \\
\text { I-V (G) }\end{array}$ & $\begin{array}{l}\text { Enrolment VI- } \\
\text { VIII (G) }\end{array}$ & $\begin{array}{l}\text { Enrolment I- } \\
\text { V(P) }\end{array}$ & $\begin{array}{l}\text { Enrolment } \\
\text { VI-VIII (P) }\end{array}$ & $\begin{array}{l}\text { Retention } \\
\text { Rate }\end{array}$ & $\begin{array}{l}\text { Transition } \\
\text { Rate }\end{array}$ \\
\hline 2007 & 101153429 & 32498650 & 32736432 & 18353943 & 73.7 & 81.1 \\
\hline 2008 & 99485579 & 33722832 & 34842446 & 19613550 & 74.9 & 82.7 \\
\hline 2009 & 96222886 & 34368617 & 37099124 & 20055714 & 74 & 83.5 \\
\hline 2010 & 94088108 & 36001733 & 38235561 & 20882615 & 73.4 & 85.2 \\
\hline 2011 & 91650493 & 37745355 & 41898099 & 22965970 & 75.9 & 87.1 \\
\hline 2012 & 86491505 & 38567724 & 44481644 & 25265429 & 80.1 & 86.7 \\
\hline 2013 & 83121238 & 38839624 & 45665198 & 25566596 & 82.4 & 89.6 \\
\hline 2014 & 79952199 & 39021735 & 46626355 & 26929030 & 83.7 & 89.7 \\
\hline 2015 & 78051565 & 38869512 & 47185892 & 27463212 & 84.2 & 90.1 \\
\hline CAGR & -0.02 & 0.02 & 0.04 & .0 .04 & 0.01 & 0.01 \\
\hline
\end{tabular}

Source: DISE Reports

Table 4 shows two important indicators that play a very key role in improving learning outcomes. The pupil-teacher ratio decreased from 33 to 24, which is a good indication. In service training improves teacher's effectiveness through updating their knowledge and skills. The effectiveness of in-service training is important so that teachers can apply the knowledge acquired in teaching and learning. However, the percentage of teachers who received in service training has decreased from $36.8 \%$ to $14.9 \%$, which is an area of major concern.

Table 4. Teacher's Indicators

\begin{tabular}{|l|l|l|}
\hline Year & $\begin{array}{l}\text { Pupil- } \\
\text { Teacher } \\
\text { ratio }\end{array}$ & $\begin{array}{l}\text { received teachers } \\
\text { rervice training }\end{array}$ \\
\hline $\mathbf{2 0 0 7}$ & 33 & 36.8 \\
\hline $\mathbf{2 0 0 8}$ & 32 & 35.1 \\
\hline $\mathbf{2 0 0 9}$ & 32 & 35 \\
\hline $\mathbf{2 0 1 0}$ & 30 & 29.6 \\
\hline $\mathbf{2 0 1 1}$ & 30 & 34.2 \\
\hline $\mathbf{2 0 1 2}$ & 27 & 25.8 \\
\hline $\mathbf{2 0 1 3}$ & 26 & 22 \\
\hline $\mathbf{2 0 1 4}$ & 25 & 18.3 \\
\hline $\mathbf{2 0 1 5}$ & 24 & 14.9 \\
\hline
\end{tabular}

Source: DISE Reports 


\section{Trends in Government of India Allocation and Expenditure for Elementary Education}

Education is the most important sector of the economy. It is considered to be a public good and was included in the concurrent list of the Constitution of India in 1976. It is the responsibility of both central and state governments to maintain quality, access and equity in education. With several players involved in the financing of education, it is difficult to ascertain directly the expenditure incurred on education. First, expenditure by the Department of Education is allocated under different headings, including general education, technical education, sports and youth services, and arts and culture. Second, there are many other departments, such as the Department of Rural Development, the Department of Women and Child Welfare, etc., which make expenditure on education not included in the above-mentioned expenditure. Given the different sources of funding, it is difficult to give an accurate picture of the overall flow of funds in the education sector. This also applies to capital expenditure, which is financed mainly by other departments. It is very difficult to compile capital expenditure on the available budget documents. This study therefore focuses on the revenue expenditure of the Department of Education.Figure 1 shows the yearly total expenditure on education by the Department of Education and other departments as a percentage of GDP. From 2012 onwards, we can see a continuous increase in expenditure from 3.70 per cent to 4.38 per cent until 2016, but at a very slow rate. The compound growth rate of the percentage of total expenditure on education to GDP from 2006 to 2016 is only 0.02 per cent. But, some of our neighboring countries spend much more on education than India. For instance, countries like Bhutan spend $6.6 \%$, South Africa $6.2 \%$, Nepal $5.2 \%$ of GDP on education.

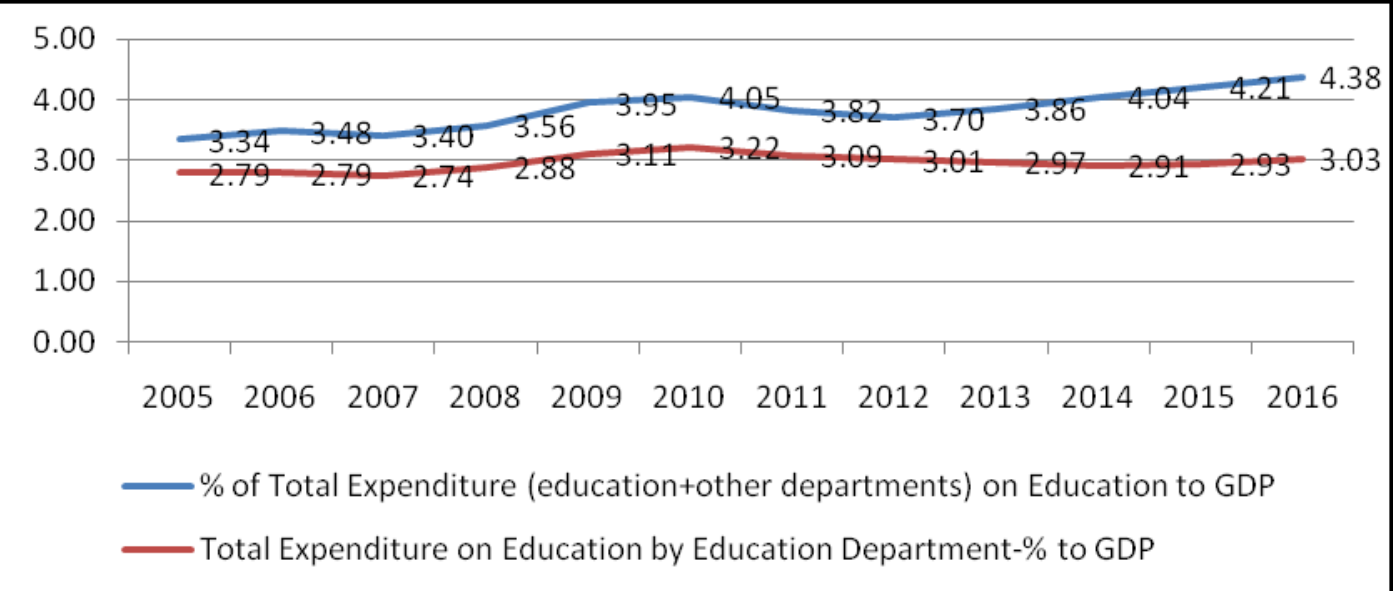

Figure 1. Percentage of Total Expenditure (Education + Other Departments) on Education to GDP Source: MHRD

The total budget expenditure on education and the shares borne by the Center and the States are shown in Figure 2. It is noted that over the last 10 years, the States have contributed an average of $75 \%$ of the total revenue expenditure on education in the country, while the center contributes around $25 \%$ to the education sector as a whole. 


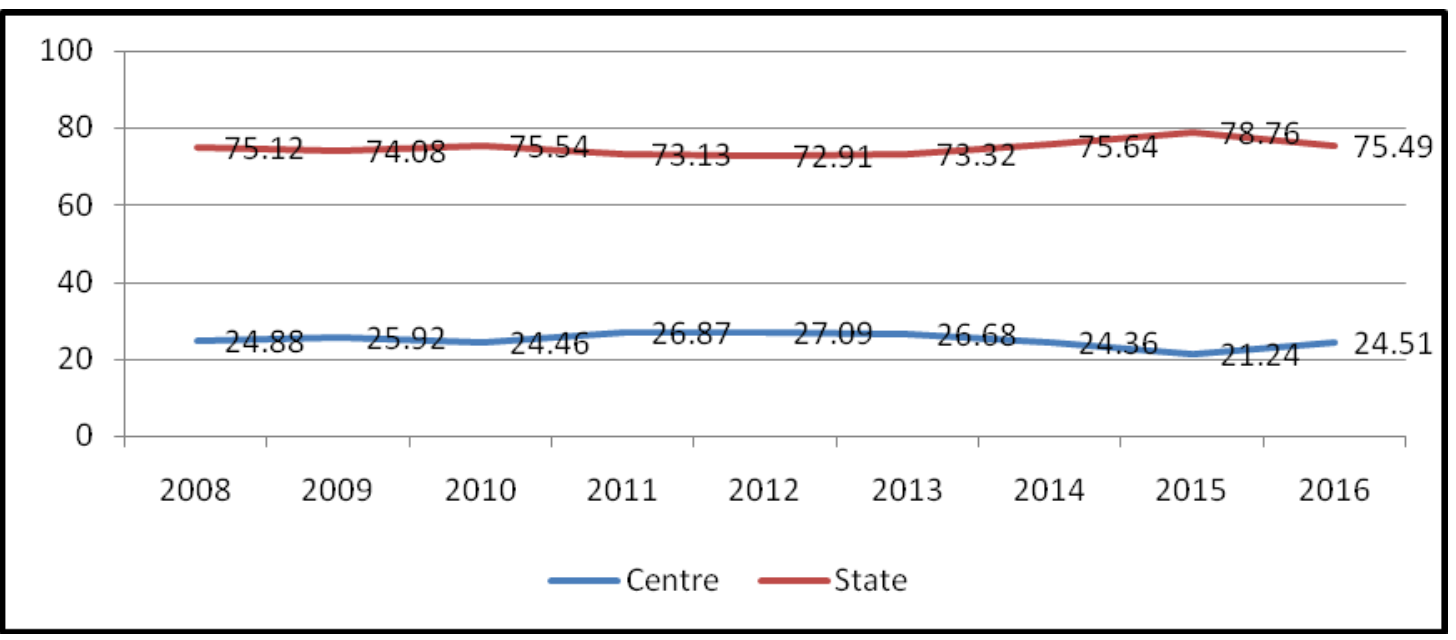

Figure 2. Percentage share of Expenditure on Education to the total expenditure (Revenue Account)

\section{Source: MHRD}

Table 5 shows Sector-wise expenditure on education by the Department of Education incurred by both the Center and the States. Elementary education accounted for 49.68 per cent of the total expenditure on education in 2016-17, followed by secondary education, which was 31.28 per cent. The University \& Higher Education share was $12.74 \%$. Elementary education, secondary education and university education account for $93 \%$ of total expenditure on education and only $7 \%$ accounts for expenditure on language development, technical education, general education and physical education.

Table 5. Sector-wise Expenditure (Plan + Non Plan) on Education by Education Department (Revenue Account) with percentage Centre and States/UTs

\begin{tabular}{|l|l|l|l|}
\hline Year & $\begin{array}{l}\text { Elementary } \\
\text { Education }\end{array}$ & $\begin{array}{l}\text { Secondary } \\
\text { Education }\end{array}$ & $\begin{array}{l}\text { University \& Hr. } \\
\text { Education }\end{array}$ \\
\hline 2008 & 52.13 & 29.34 & 11.89 \\
\hline 2009 & 49.97 & 30.67 & 12.76 \\
\hline 2010 & 49.14 & 31.00 & 12.79 \\
\hline 2011 & 50.21 & 30.6 & 12.91 \\
\hline 2012 & 50.36 & 30.04 & 13.12 \\
\hline 2013 & 50.72 & 30.06 & 12.97 \\
\hline 2014 & 51.65 & 29.06 & 12.63 \\
\hline 2015 & 50.96 & 30.00 & 12.84 \\
\hline 2016 & 49.68 & 31.28 & 12.74 \\
\hline Mean & $\mathbf{5 0 . 5 4}$ & $\mathbf{3 0 . 2 3}$ & $\mathbf{1 2 . 7 4}$ \\
\hline Std.Dev & $\mathbf{0 0 . 9 4}$ & $\mathbf{0 . 7 3}$ & $\mathbf{0 . 3 5}$ \\
\hline Max & $\mathbf{5 2 . 1 3}$ & $\mathbf{3 1 . 2 8}$ & $\mathbf{1 3 . 1 2}$ \\
\hline Min & $\mathbf{4 9 . 1 4}$ & $\mathbf{2 9 . 0 6}$ & $\mathbf{1 1 . 8 9}$ \\
\hline
\end{tabular}

Source:MHRD

Though at present there is no classification of plan and non plan expenditure, it is important to analyze these two types of expenditures. Plan expenditures are expenditures that are mainly made for productive purposes, such as expenditure on programs and schemes. Non-plan expenditure is expenditure on 
the operation and maintenance of existing educational infrastructure. Table 6 shows the plan and non-plan expenditure of elementary education by the Department of Education. On average, 60 per cent of the total plan expenditure by the education department is spent on elementary education and about 46 per cent is spent under the non-plan category.

Table 6: Percentage of Elementary Plan \& Non Plan expenditure on Education by Education Department (Revenue Account) to the total Plan and Non Plan expenditure

\begin{tabular}{|l|l|l|l|}
\hline Year & Plan & $\begin{array}{l}\text { Non- } \\
\text { Plan }\end{array}$ & Total \\
\hline 2008 & 62.14 & 47.15 & 52.13 \\
\hline 2009 & 59.58 & 45.92 & 49.97 \\
\hline 2010 & 58.39 & 45.16 & 49.14 \\
\hline 2011 & 60.04 & 45.59 & 50.21 \\
\hline 2012 & 59.09 & 45.9 & 50.36 \\
\hline 2013 & 60.59 & 45.57 & 50.72 \\
\hline 2014 & 60.87 & 46.83 & 51.65 \\
\hline 2015 & 60.56 & 46.40 & 50.96 \\
\hline 2016 & 57.90 & 46.05 & 49.68 \\
\hline Mean & $\mathbf{5 9 . 6 3}$ & $\mathbf{4 6 . 0 6}$ & $\mathbf{5 0 . 5 4}$ \\
\hline Std.Dev & 1.09 & 0.63 & 0.94 \\
\hline Maximum & 60.87 & 47.15 & 52.13 \\
\hline Minimum & 57.9 & 45.16 & 49.14 \\
\hline
\end{tabular}

Source:MHRD

Furthermore, in recent years, the central government has increased its spending on Elementary Education through centrally sponsored schemes such as Sarva Shiksha Abhiyan (SSA). This scheme is financed by both central and state governments, with a major contribution from the central government. Since 2000, SSA has been implemented to universalize elementary education and to promote the retention of children in school. After the RTE Act, 2009 was enacted, SSA was subsumed under it. RTE guarantees the right to free and compulsory elementary education for children between the ages of 6 and 14 in a neighborhood school. The following table shows SSA expenditure from the center for the year 2008 to 2018. Centrally sponsored schemes are a channel through which the central government will add resources to the state education sector. Many studies show that, following the implementation of the SSA, the proportion of out-of-school children in India has decreased and the school infrastructure has improved (Rajeshwari (2014), MHRD (2017). Out of total centrally sponsored schemes almost $50 \%$ is spent on SSA scheme.SSA per capita expenditure is steadily increasing from 2010 to 2018. One of the reasons for this may be the decline in public school enrolment.

Table 7. Sarva Shiksha Abhiyan (SSA) Expenditure from Centre

\begin{tabular}{|c|c|c|c|c|}
\hline Year & $\begin{array}{l}\text { SSA Allocation } \\
\text { from Centre (Rs } \\
\text { in Crores) }\end{array}$ & $\begin{array}{l}\text { Total (Centrally } \\
\text { Sponsored Schemes) } \\
\text { (Rs.in Crores) }\end{array}$ & $\begin{array}{l}\% \text { of SSA Allocation to } \\
\text { the Total (Centrally } \\
\text { Sponsored Schemes) }\end{array}$ & $\begin{array}{l}\text { Per capita SSA } \\
\text { Expenditure }\end{array}$ \\
\hline 2008 & 5387.37 & 26026.57 & 20.70 & - \\
\hline 2009 & 12825.44 & 24466.07 & 52.42 & - \\
\hline 2010 & 17202.10 & 36342.00 & 47.33 & 2455 \\
\hline 2011 & 19088.50 & 41451.00 & 46.05 & 2907 \\
\hline
\end{tabular}




\begin{tabular}{|l|l|l|l|l|}
\hline 2012 & 23872.58 & 45631.43 & 52.32 & 3525 \\
\hline 2013 & 23947.93 & 50136.30 & 47.77 & 3275 \\
\hline 2014 & 24092.63 & 45722.41 & 52.69 & 3523 \\
\hline 2015 & 23350.54 & 42186.50 & 55.35 & 3783 \\
\hline 2016 & 21685.42 & 42989.43 & 50.44 & 4385 \\
\hline 2017 & 23500.00 & 47006.25 & 49.99 & $4887^{*}$ \\
\hline 2018 & 26128.81 & 50000.00 & 52.26 & $5589^{*}$ \\
\hline CAGR & $\mathbf{0 . 1 5}$ & $\mathbf{0 . 0 6}$ & $\mathbf{0 . 0 8}$ & $\mathbf{0 . 1 0}$ \\
\hline
\end{tabular}

\section{Source: Various Budget Documents}

*- estimated

\section{Trends in Learning Outcomes}

Although there is an increase in per capita SSA expenditure on education, learning outcomes however are poor in government schools. It is very important to note that merely increasing enrolment and improving infrastructure does not ensure learning. Many surveys in India have shown the poor quality of school education.Looking at the type of activities for which SSA expenditure is incurred, we find that a significant proportion of the funds in the program are set aside for the payment of salaries to teachers and the financing of infrastructure.Teacher training is a continuous process, with pre-service and in-service training being its inseparable components. In March 2017; the central government amended the RTE Act by extending the timeline for teacher training from 2015 to 2019.The following table shows the Government Expenditure Share of Teacher training in the Total Expenditure of School Education. In 2016-17, the central government brought the teacher training program under the umbrella of the National Education Mission (NEM).

However, the share of teacher education budget in the school budget has consistently been around $1 \%$ (budget estimates) over the last 10 years, showing that teacher education has been given low priority. Although over time, the government has addressed the issue of untrained teachers mostly through in-service teacher training under both the state and central government of the SSA, it has failed to spend enough on capacity building.

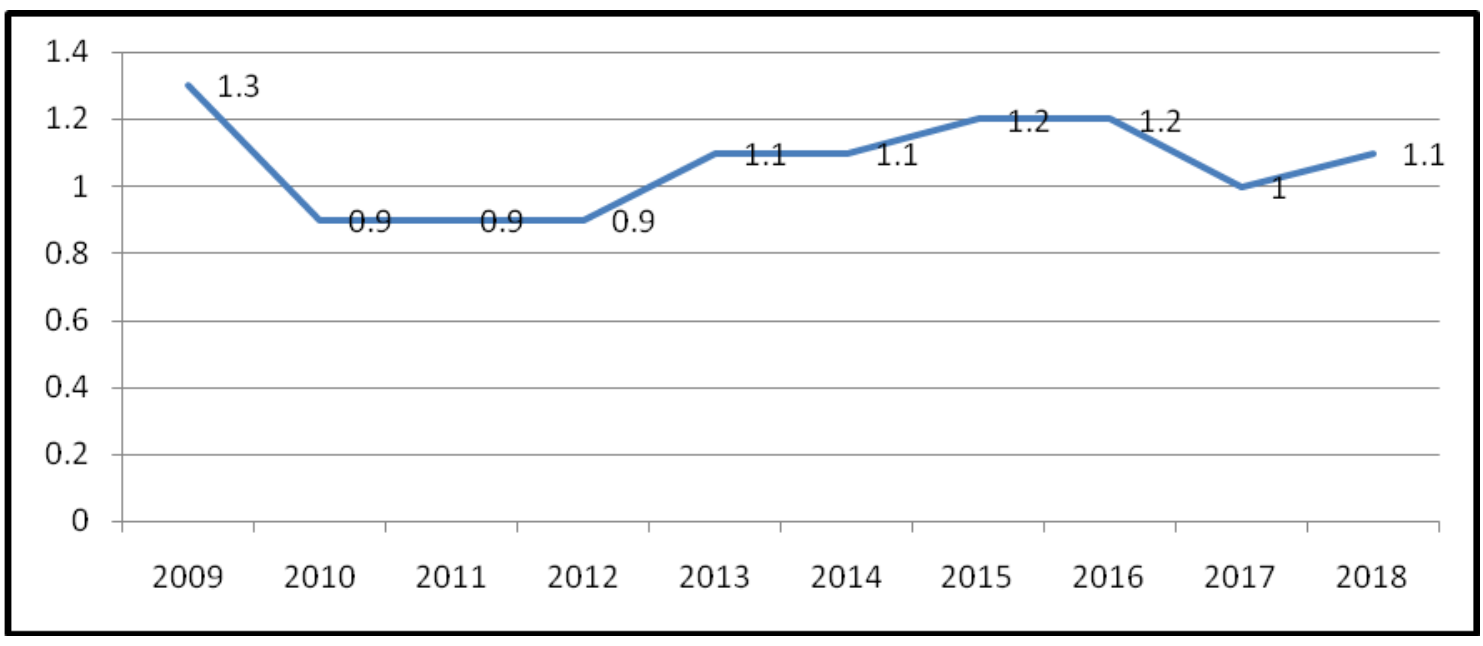

Figure 3. Government Expenditure Share of Teacher Training in Total Expenditure of School Education, 2009-10 to 2018-19

\section{Source:MHRD}

Elementary education is the foundation of the education system. Strengthening elementary education is feasible in order to achieve the goal of universal access to quality education. But the greatest challenge in elementary education is the poor level of learning outcomes. Despite a higher level of enrolment 
and an increase in infrastructure, the value addition is still weak. ASER is a national household survey that provides a report on child schooling and learning for a representative sample of children across rural India. ASER continues to be one of the most important sources of information on the basic skills of children across the country.

Table 8: Learning Indicators

\begin{tabular}{|l|l|l|l|}
\hline & $\begin{array}{l}\text { \% Children in } \\
\text { government schools } \\
\text { in Std Vho can } \\
\text { read Std II level text }\end{array}$ & $\begin{array}{l}\text { government in } \\
\text { schools in Std V } \\
\text { who can do } \\
\text { division }\end{array}$ & $\begin{array}{l}\text { \% Children in } \\
\text { Std III who can } \\
\text { do at least } \\
\text { subtraction }\end{array}$ \\
\hline 2008 & 53.10 & 34.40 & - \\
\hline 2009 & $\mathbf{5 1 . 9 0}$ & $\mathbf{3 4 . 1 5}$ & - \\
\hline 2010 & 50.70 & 33.90 & - \\
\hline 2011 & $\mathbf{4 6 . 2 0}$ & $\mathbf{2 7 . 1 0}$ & - \\
\hline 2012 & 41.70 & 20.30 & 19.80 \\
\hline 2013 & $\mathbf{4 1 . 9 5}$ & $\mathbf{2 0 . 5 0}$ & $\mathbf{1 8 . 5 0}$ \\
\hline 2014 & 42.20 & 20.70 & 17.20 \\
\hline 2015 & $\mathbf{4 1 . 9 5}$ & $\mathbf{2 0 . 9 0}$ & $\mathbf{1 8 . 7 5}$ \\
\hline 2016 & 41.70 & 21.10 & 20.30 \\
\hline $\mathbf{2 0 1 7}$ & $\mathbf{4 2 . 9 5}$ & $\mathbf{2 1 . 9 0}$ & $\mathbf{2 0 . 6 0}$ \\
\hline 2018 & 44.20 & 22.70 & 20.90 \\
\hline CAGR & $\mathbf{- 0 . 0 1}$ & $\mathbf{- 0 . 0 3}$ & $\mathbf{0 . 0 1}$ \\
\hline
\end{tabular}

Source: ASER Reports

The ASER reading test assesses whether a child can read letters, words, a simple paragraph at Standard I level of difficulty, or a story at Standard II level of difficulty. The test is administered one by one to all children in age groups 5 to 16 and the child is labeled at the highest level that can be reached. The percentage of children in Standard V government schools able to read Standard II text has decreased from 53.10 per cent (2008) to 44.20 per cent (2018). But if we look at the individual performances of the different states, we see a different picture. States such as Kerala, Maharashtra, Punjab, Uttarakhand, Haryana, Chhattisgarh, Assam and Madhya Pradesh have shown positive growth over the last four years, with Karnataka, Himachal Pradesh, Odisha and Uttar Pradesh showing a slight increase over the last two years.

The ASER arithmetic test assesses whether a child can recognize numbers from 1 to 9 , recognize numbers from 10 to 99, have a 2-digit number subtraction problem with borrowing, or have a numerical division problem (3-digit by 1-digit) resolved correctly. The tasks are administered one by one to all children in age groups 5 to 16 , and the child is identified at the highest level that can be attained.

Just as reading level the percentage children in government schools in Standard V who can do division at national level has decreased from $34.40 \%$ to $22.70 \%$. Again, the small improvements over the last four to six years with respect to different states are not enough to bring the positive impact at the national level.Only few states like Himachal Pradesh, Punjab has shown positive changewhere as many other stateslike Assam, Gujarat, Karnataka, Rajasthan, and Jharkhand have shown very poor performance with respect to the same indicator. Similarly, percentage of children in Standard III who can do at least subtraction has slightly increased from $19.80 \%$ to $20.90 \%$.

Though the 1992 National Education Policy stressed the need for a substantial improvement in the quality of education in order to achieve essential levels of learning we cannot see that improvement in some of the learning indicators. Each row shows the variation in children's reading levels within a given grade. It is disappointing to see that not even $50 \%$ of the students read standard I text book. Among children in Std I of 
government school, 39\% cannot even read letters, $29.6 \%$ can read letters but not words or higher, 15.2\%can read words but not a Std I level text or higher, and only 16.2\% can read a Std I level text or higher.

Table 9: Distribution of children's reading ability within each grade 2019 in Government School

\begin{tabular}{|l|l|l|l|l|}
\hline Std & $\begin{array}{l}\text { Not even } \\
\text { letter }\end{array}$ & Letter & Word & $\begin{array}{l}\text { Std I level } \\
\text { text }\end{array}$ \\
\hline Std I & 39 & 29.6 & 15.2 & 16.2 \\
\hline Std II & 22.3 & 23.5 & 19.4 & 34.8 \\
\hline Std III & 14.7 & 18.1 & 16.5 & 50.8 \\
\hline
\end{tabular}

Source: ASER Reports

The following table shows early numerical skills of Standard I to Standard III students in the year 2019. Among children in standard III, 5.6\% students cannot even recognize numbers $1-9$ and $22.2 \%$ of students can recognize up to 9 but cannot recognize up to 99 . By implication one fourth of the students enrolled in standard III do not have numeracy attainments beyond the first 9 whole numbers in the numerical system.

Table 10: Distribution of children's ability to recognize numbers within each grade 2019

\begin{tabular}{|l|l|l|l|}
\hline Std & Not even1-9 & $\begin{array}{l}\text { Number } \\
\text { recognition } \\
(1-9)\end{array}$ & $\begin{array}{l}\text { Number } \\
\text { recognition } \\
(11-99)\end{array}$ \\
\hline Std I & 26.9 & 32 & 41.1 \\
\hline Std II & 11.6 & 27.1 & 61.3 \\
\hline Std III & 5.6 & 22.2 & 72.2 \\
\hline
\end{tabular}

Source: ASER Reports

Over a period of time if we look at the performance of Standard III students, there is not much change in the performance level. The table below table shows distribution of reading in Standard III from 2010 to 2018.

Table 11: \% Children able to read at different levels(Std III, Government schools)

\begin{tabular}{|l|l|l|l|l|l|}
\hline Year & $\begin{array}{l}\text { Not even } \\
\text { letter }\end{array}$ & Letter & Word & $\begin{array}{l}\text { Std I level } \\
\text { text }\end{array}$ & $\begin{array}{l}\text { Std. } \\
\text { 2text }\end{array}$ \\
\hline 2010 & 6.5 & 19.9 & 31.2 & 25.7 & 16.8 \\
\hline 2011 & 10.1 & 25.3 & 29.4 & 20.5 & 14.7 \\
\hline 2012 & 14.8 & 29.3 & 23.6 & 15.7 & 16.7 \\
\hline 2013 & 15.9 & 28.7 & 22.8 & 16.7 & 15.9 \\
\hline 2014 & 19.2 & 28.8 & 20.3 & 14.5 & 17.2 \\
\hline 2015 & 18.2 & 28.3 & 20.3 & 15.0 & 18.3 \\
\hline 2016 & 17.1 & 27.8 & 20.3 & 15.5 & 19.3 \\
\hline 2017 & 16.4 & 26.9 & 20.9 & 15.7 & 20.1 \\
\hline 2018 & 15.7 & 26.0 & 21.5 & 15.9 & 20.9 \\
\hline
\end{tabular}

Source: ASER Reports

Table 12 shows the proportion ofchildren in Standard III who canread Standard II level text book both in Government and Private schools. In the year 2018, only 20.9\% of students in Standard III who can read Standard II textbooks. Performance in private school is better than government school.

Table 12: Trends over time Reading in Standard III by school type 2012, 2014, 2016 and 2018 


\begin{tabular}{|l|l|l|}
\hline \multirow{2}{*}{ Year } & \multicolumn{2}{|l|}{$\begin{array}{l}\text { \% Children in Std III who can read Std } \\
\text { II level text }\end{array}$} \\
\hline & Govt & Private \\
\hline 2012 & 16.7 & 33.8 \\
\hline 2014 & 17.2 & 37.8 \\
\hline 2016 & 19.3 & 38.0 \\
\hline 2018 & 20.9 & 40.6 \\
\hline \multicolumn{3}{|c|}{ Source: ASER Reports }
\end{tabular}

Table 13 shows the percentage of children in standard V who can read Standard III level text book and the percentage of children in standard VIII who can read Standard II level text book. It can be observed that only $44.2 \%$ of the children in standard V can read Standard III text book in government school where as it is $65.1 \%$ in private school. More disappointing part is that still $40 \%$ of the children in standard VIII in government schools cannot read standard II level text book. Further another interesting matter to be observed is in the information provided in Tables 11-13 the highest levels of learning outcomes tested is one or two grades lower than the present school grade where the child is officially present as per his or her promotion. In fact as per Table - 13 the attainment of learning outcome investigated is for children in standard VIII, the last phase of middle school being able to read standard II level text which is a primary school level text. It is actually downgraded by five levels of school grades. None of the enrolled students are able to actually read text at the school grade levels they are currently enrolled. This not only questions the efficacy of teaching quality but also testing quality for with learning outcome levels being lower from the grade in which the student is currently studying officially how did one get promoted to the present grade.

Table 13: Trends over timeReading in Standard V and Standard VIII by school type2012, 2014, 2016 and 2018

\begin{tabular}{|l|l|l|l|l|}
\hline & \multicolumn{3}{|c|}{$\begin{array}{l}\text { \% Children in Std VIII } \\
\text { \%ear Children in Std V who } \\
\text { can read Std II level text }\end{array}$} & \multicolumn{2}{l|}{$\begin{array}{l}\text { who can read Std II } \\
\text { level text }\end{array}$} \\
\hline & Govt & Private & Govt & Private \\
\hline 2012 & 41.7 & 61.2 & 73.4 & 84.2 \\
\hline 2014 & 42.2 & 62.6 & 71.5 & 82.4 \\
\hline 2016 & 41.7 & 63 & 70 & 81 \\
\hline 2018 & 44.2 & 65.1 & 69 & 82.9 \\
\hline \multicolumn{5}{|c|}{ Source: ASER Reports } \\
\hline
\end{tabular}

Source: ASER Reports

\section{Association between expenditure and learning outcome}

Proper funding is one of the components of education that leads to better educational performance, but we cannot simply assume that an increase in student expenditure means better performance.It will not be appropriate to run any type of correlation or regression as the data of learning outcome is only for rural India where as the expenditure data considers both rural and urban India. Therefore, this study tries to compare the compound growth rate over 10 years for different variables.

The following table shows the compound growth rate of learning indicators and expenditure indicators for the time period 2008 to 2018. We can notice that the compound growth rate is negative for most of the learning outcome indicators where as it is positive growth for expenditure indicators. This shows that learning outcome and expenditure growth is not matching with each other. The learning outcomes of the last 10 years have not improved much.

Table 14: Compound Growth Rate of Some of the Learning Outcome Indicators and Expenditure Indicators 


\begin{tabular}{|l|l|}
\hline Variables & $\begin{array}{l}\text { Compound Growth } \\
\text { Rate } \\
\text { for the year 2008- } \\
\mathbf{2 0 1 8}\end{array}$ \\
\hline $\begin{array}{l}\text { \% Children in government schools in Std V who can } \\
\text { read Std II level text }\end{array}$ & -0.01 \\
\hline $\begin{array}{l}\text { \% Children in government schools in Std V who can do } \\
\text { division }\end{array}$ & -0.03 \\
\hline $\begin{array}{l}\text { \% Children who can read a Std II level text, Std V } \\
\text { government school }\end{array}$ & -0.01 \\
\hline \% Children in Std III who can do at least subtraction & 0.01 \\
\hline SSA Allocation from Centre (Rs in Crores) & 0.15 \\
\hline Total (Centrally Sponsored Schemes) (Rs.in Crores) & 0.06 \\
\hline $\begin{array}{l}\text { \% of SSA Allocation to the Total (Centrally Sponsored } \\
\text { Schemes) }\end{array}$ & 0.08 \\
\hline Per capita SSA Expenditure & 0.10 \\
\hline
\end{tabular}

\section{CONCLUSION}

It is well known that education is one of the important factors of economic development.Expenditure on education is always considered as investment in human capital as it helps in skill formation and therefore improves ability to work. Public spending on education is of great importance as it plays a critical role in promoting economic growth and development. But, it is not only the expenditure but also the learning outcomeplays very important role in the growth of the economy. Learning outcomes describe the measurable skills, abilities, knowledge or values that students should be able to demonstrate as a result of completing different levels level of education.But the basic question is whether there exists any association between public expenditure per student on elementary education and learning outcomes?Looking at the spending on schooling, it is gradually rising. While there is a substantial increase in the enrollment ratio, the pupil teacher ratio and the school infrastructure, there has been little improvement in learning outcomes, especially in government schools. In this context it is important to analyse whether increasing education expenditure translates into better learning outcomes. As to the teaching dimension of the educational experience, there are numerous aspects that deserve attention. India is clearly lacking in terms of teacher specialization with $8.2 \%$ schools being single-teacher schools, according to DISE.In addition to this, teachers are not subjected to rigorous in service training programme. In terms of teacher training, India has a long way to go. In countries like Singapore teachers require to undergo 100 hours of compulsory training annually to stay updated with the latest technology and curriculum.However, we also need to remember that changing the entire scene of education in the country will definitely take time. It is impossible to improve education outcomes overnight.It is not enough for the government to allocate funds for education sector but it is important that efforts have to betaken tomonitor the spending, to ensure that the funds are translated into learning outcomes. Education systems should provide adequate resources to ensure that all students have the opportunity to receive a highquality basic education (Berne and Stiefel 1984; Underwood 1995).

\section{REFERENCES}

Anuradha De and Tanuka Endow (2008). "Public Expenditure on Education in India: Recent Trends and Outcomes", RECOUP Working Paper No.18

Annual Status of Education Report, Various Survey Reports.

Dongre, Kapur, Tewary (2014). "How much does India Spend Per Student on Elementary Education?", Centre for Policy Research, New Delhi.

François Leclercq (2004). The Relationship Between Educational Expenditures and Outcomes, EFA Global Monitoring Report 2005, UNESCO.

Iyer, T. (2009). "Is public expenditure on primary education effective? Evidence from districts across India", Graduation thesis in Economics, Trinity College of Duke University 
Kundu and Biswas (2019). Learning Outcomes in Elementary Education in Rural India: An Inter-State Comparisons, Journal of Rural Development, Vol 38 (1).

Rajeshwari UR, Emmanual PJ (2014). Social Sector Expenditure in Karnataka with Special Reference to Education and Health, Centre for Publications, Christ University, Bangalore.

Samer Al-Samarrai (2003). Financing primary education for all: public expenditure and education outcomes in Africa, Report, Institute of Development Studies, University of Sussex, United Kingdom

Thiajasmina (2016). Public Spending and Learning Outcomes of Basic Education at the District Level in Indonesia, Economics and Finance in Indonesia, Vol. 62 No. 3, December 2016: 180-190.

Unified District Information System for Education, Department of School Education, MHRD, Govt. of India 